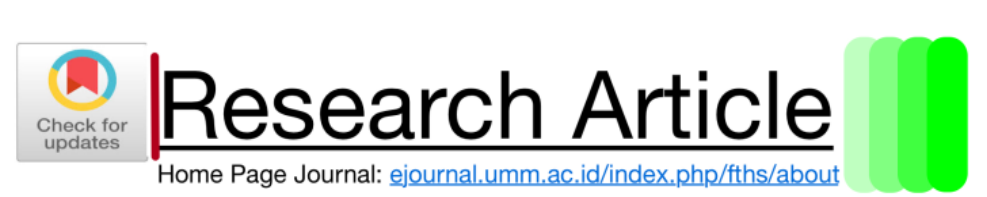

DOI. 10.22219/fths.v5i1.18760

Received: 20 November 2021

Accepted: 25 Januari 2022

Available online: 31 Januari 2022

\title{
Karakteristik Organoleptik Yoghurt Sinbiotik dengan Penambahan Inulin Pure Pisang Barangan (Musa acuminata Colla)
}

\author{
Friska Yuana Amelia*, Warkoyo ${ }^{1}$, Hanif Alamudin Manshur ${ }^{1}$, Afifa Husna ${ }^{1}$ \\ ${ }^{1}$ Program Studi Teknologi Pangan, Fakultas Pertanian Peternakan, Universitas Muhammadiyah \\ Malang, Malang Indonesia. \\ Corresponding author email : friskaamelia906@gmail.com
}

\begin{abstract}
Synbiotic was a combination of prebiotics and probiotics. One of the agricultural commodities that contains prebiotics was "barangan banana". Barangan banana and inulin as prebiotics and Lactobacillus casei as a probiotics can produce synbiotic beverages, To obtain synbiotic beverages, it needs a drink formulation that utilizes Pisang Ambon and use inoculum $L$. casei as a stater and adding inulin to obtain preferred synbiotic beverages. The objective of this research determine the effect of the comparison of Barangan banana puree and skim milk on the organoleptic characteristics of synbiotic yogurt. This research was divided into two steps, the first stage was the optimization of the appropriate ratio of banana puree and skim milk through an organoleptic test. The second stage is the physicochemical and microbiological analysis of the formulation selected in the first stage. The first phase of the experimental design used a simple RAK (Randomized Block Design) with one factor. he results of the analysis of synbiotic yogurt containing $p H 4.02 \%$, total titrated acid (TAT) $1.05 \%$, inulin content $2.88 \%$, proximate analysis $0.87 \%$ ash content, fat content $4.10 \%$, protein content $4.58 \%$. Analysis of the physical quality of synbiotic drinks with a viscosity of $11.05 \%$. Analysis of microbiological quality, synbiotic yogurt has a total number of lactic acid bacteria, namely on the 7th day $1.29 \times 109 \mathrm{cfu} / \mathrm{ml}$ and the 8 th day of $2,42 \times 109 \mathrm{cfu} / \mathrm{ml}$. The overall results of the quality tests carried out are in accordance with the requirements of SNI 01.2981-2009 regarding yogurt. The levels of probiotics and prebiotics possessed by synbiotic yogurt have met the requirements so that the product can be said to be a synbiotic food product.
\end{abstract}

Keywords : formulation, microbiology, prebiotic

\begin{abstract}
Abstrak. Sinbiotik merupakan kombinasi antara prebiotik dan probiotik. Salah satu komoditas hasil pertanian yang mengandung prebiotik adalah pisang barangan. Penggunaan pisang barangan sebagai prebiotik dan L. casei sebagai probiotik dapat menghasilkan produk yoghurt sinbiotik, selain itu diperlukan suatu formulasi yoghurt sinbiotik yang memanfaatkan pure pisang barangan dan susu skim agar diperoleh yoghurt sinbiotik yang disukai oleh panelis. Penelitian ini bertujuan untuk mengetahui pengaruh perbandingan pure pisang barangan dan susu skim terhadap karakteristik organoleptik yoghurt sinbiotik. Penelitian ini dilakukan dalam dua tahap yaitu tahap pertama adalah optimasi perbandingan pure pisang dan susu skim yang sesuai melalui uji organoleptik. Tahap kedua adalah analisis fisikokimia dan mikrobiologi dari formulasi terpilih pada tahap pertama. Rancangan percobaan tahap pertama menggunakan RAK (Rancangan Acak Kelompok) sederhana dengan satu faktor. Hasil analisis yoghurt sinbiotik mengandung $\mathrm{pH}$ $4,02 \%$, total asam tertitrasi (TAT) 1,05\%, kadar inulin 2,88\%, analisis proksimat kadar abu 0,87\%, kadar lemak 4,10\%, kadar protein 4,58\%. Analisis kualitas fisik minuman sinbiotik dengan viskositas $11,05 \%$. Analisis kualitas mikrobiologi, yoghurt sinbiotik memiliki jumlah
\end{abstract}


total bakteri asam laktat yaitu pada hari ke-7 $1,29 \times 10^{9} \mathrm{cfu} / \mathrm{ml}$ dan hari ke-8 sebesar $2,42 \times 10^{9}$ $\mathrm{cfu} / \mathrm{ml}$. Keseluruhan hasil uji mutu yang dilakukan telah sesuai dengan persyaratan SNI 01.2981-2009 tentang yoghurt. Kadar probiotik dan prebiotik yang dimiliki oleh yoghurt sinbiotik telah memenuhi syarat sehingga produk tersebut dapat dikatakan sebagai produk pangan sinbiotik.

Kata Kunci : formulasi, mikrobiologi, prebiotik

\section{PENDAHULUAN}

Konsumsi pangan masyarakat di Indonesia terhadap produk hasil fermentasi, semakin meningkat seiring berkembangnya bioteknologi. Konsumsi produk fermentasi di Indonesia pada tahun 2020 menurut, Kementerian Perindustrian mengalami peningkatan sebanyak 225,98\%, angka tersebut diperkirakan akan meningkat tiap tahunnya. Seiring berkembangnya produk fermentasi dikalangan masyarakat sekarang sudah banyak beredar yoghurt sinbiotik di Indonesia, untuk meningkatkan mutu dan kualitas produk fermentasi. Sinbiotik merupakan kombinasi antara probiotik dan prebiotik (Desnilnasari\&Lestari, 2014). Probiotik merupakan mikroorganisme hidup yang ditambahkan kedalam suatu produk serta dapat memberikan manfaat kesehatan terhadap inangnya pada jumlah tertentu, prebiotik merupakan komponen makanan yang tidak dapat dicerna oleh tubuh namun mempunyai pengaruh baik terhadap inang dengan memicu aktivitas pertumbuhan bakteri kolon (Voidarou, 2013).

Penambahan prebiotik dalam yoghurt mampu meningkatkan fungsi probiotik, yaitu membantu meningkatkan pertumbuhan dan viabilitas satu atau lebih bakteri probiotik (Hilam dkk., 2015). Menurut Kementrian Perindustrian (2020) di Indonesia yoghurt sinbiotik yang sudah banyak beredar dimasyarakat saat ini berkembang sangat pesat, seperti yang kita ketahui yoghurt sinbiotik yang banyak beredar di masyarakat adalah yoghurt dengan penambahan buahbuahan. Komponen prebiotik secara alami banyak ditemukan pada kelompok oligosakarida, salah satunya adalah pisang. Pisang juga berpotensi sebagai sumber inulin, pemanfaatan inulin selain merangsang pertumbuhan aktivitas bakteri probiotik juga sebagai pemenuhan produk sinbiotik. Menurut (Franck dan De Leenheer, 2005) menyatakan sifat fisiologis dari suatu produk sinbiotik dikatakan baik jika mengandung inulin 1-3\%. Pemanfaatan inulin sebagai pemenuhan prebiotik dalam produk minuman sinbiotik sebagai syarat minuman berprobiotik.

Pengembangan minuman sinbiotik, dengan menggunakan pisang Barangan (Musa acuminata Colla). Pisang jenis ini mengandung gula yang tinggi yang diperlukan sebagai substrat oleh bakteri, rasanya yang manis daging buah yang tidak terlalu lembek dan tidak berbiji, selain itu aroma pisang harum dan ketersediaan nya juga melimpah. Kandungan kadar inulin pada pisang 
barangan yang tinggi sebesar 4,27\%, dapat dimanfaatkan sebagai prebiotik. Pengembangan minuman sinbiotik menggunakan jenis pisang barangan diharapkan, dapat meningkatkan nilai pangan fungsional minuman sinbiotik, serta meningkatkan nilai guna pisang, selain itu dengan pemanfaatan kandungan inulin pisang barangan yang tinggi sebesar 4,27\% menurut (Wahyuningsih, 2014), dapat memenuhi standart minuman berprebiotik. Penelitian ini diharapkan dapat mengetahi pengaruh formulasi pure pisang barangan dan susu skim terhadap karakteristik minuman sinbiotik serta mengetahui mutu minuman sinbiotik dengan parameter uji fisikokimia dan mikrobiologi.

\section{METODOLOGI PENELITIAN}

\section{Alat dan Bahan}

Alat yang digunakan untuk penelitian pembuatan yoghurt sinbiotik adalah pisau, chopper, panci, ledle (Centong pengaduk), cup, kompor. Alat-alat yang digunakan untuk analisis yaitu magnetic stirer, water bath, almari pendingin, thermometer, timbangan analitik, pH meter, erlenmeyer, cawan porselen, tanur, desikator, cawan porslen, oven, labu kjeldal, alat destilasi, corong, gelas ukur, viscometer, jarum ose, mikropipet, tabung reaksi, rak tabung reaksi, cawan petri, bunsen, vortex, autoklaf, inkubator.

Bahan yang digunakan untuk penelitian pembuatan yoghurt sinbiotik adalah pisang barangan yang diperoleh dari petani Pasurjambe, Lumajang Jawa Timur, susu skim, dan kultur bakteri Lactobacilus casei, glukosa. Bahan yang digunakan untuk analisis mikrobiologi dan kimia MRSA (Himedia), dan larutan pengencer $\mathrm{NaCl}(0,85 \%)$, buffer, aquades, PP (Phenolphtalein) 1\%, $\mathrm{NaOH} \mathrm{0,1} \mathrm{N,}$ $\mathrm{NaOH} 60 \%, \mathrm{Na}_{2} \mathrm{~S}_{2} \mathrm{O}_{3} 5 \%, \mathrm{HCl} 0,02 \%$, pelarut benzene.

\section{Rancangan Penelitian dan Analisis Data}

Penelitian ini dilakukan dua tahapan yaitu, tahap pertama formulasi pure pisang barangan dan susu skim yang tepat melalui uji organoleptik. Tahap kedua analisis fisikokimia dan mikrobiologi dari formulasi terpilih pada tahap pertama. Penelitian ini menggunakan rancangan percobaan RAK (Rancangan Acak Kelompok) Sederhana dengan satu faktor. Faktor tersebut yaitu, P0 : (Pure Pisang Barangan $0 \mathrm{~mL}$ + Susu Skim $276 \mathrm{~mL}$ ), P1 : (Pure Pisang Barangan $92 \mathrm{~mL}$ + Susu Skim $184 \mathrm{~mL}$ ) P2 : (Pure Pisang Barangan 138 mL + Susu Skim $138 \mathrm{~mL}$ ) P3 : (Pure Pisang Barangan $184 \mathrm{~mL}+$ Susu Skim $92 \mathrm{~mL}$ ). Setiap level proporsi dilakukan ulangan sebanyak $3 \mathrm{kali}$. Analisa statistik dilakukan dengan ANOVA pada tingkat kepercayaan $\alpha=5 \%$ untuk mengetahui pengaruh perlakuan terhadap sifat fisikokimia dan organoleptik stik, apabila menunjukkan pengaruh nyata akan dilanjutkan dengan uji DMRT pada $\alpha=5 \%$. 


\section{Pembuatan Pure Pisang}

Pisang yang dipilih sebagai bahan baku adalah pisang barangan, pisang jenis ini mengandung gula yang tinggi yang diperlukan sebagai substrat oleh bakteri, rasanya yang manis daging buah yang tidak terlalu lembek, dan tidak berbiji. Karakteristik pisang barangan matang penuh dengan indeks warna sekitar 6 dan tidak keras saat ditekan. Proses pembuatan puree pisang dilakukan pencucian, dan pengupasan, kemudian pisang dipanaskan suhu $70^{\circ} \mathrm{C}$ selama 7 menit, dilakukan pemotongan ukuran $\pm 0,5-1 \mathrm{~cm}$, setelah itu dihancurkan menggunakan chopper (Ferawati, 2009).

\section{Pembuatan Yoghurt Sinbiotik}

Proses pembuatan yoghurt sinbiotik perbandingan susu skim dengan pure pisang P0 : (Pure Pisang Barangan $0 \mathrm{~mL}+$ Susu Skim $276 \mathrm{~mL}$ ), P1 : (Pure Pisang Barangan $92 \mathrm{~mL}$ + Susu Skim $184 \mathrm{~mL}$ ) P2 : (Pure Pisang Barangan $138 \mathrm{~mL}+$ Susu Skim $138 \mathrm{~mL}$ ) P3 : (Pure Pisang Barangan $184 \mathrm{~mL}$ + Susu Skim $92 \mathrm{~mL}$ ), ditambahkan glukosa sebanyak $3 \%$, lalu dilakukan homogenisasi selama 3 menit, pemanasan dengan menggunakan waterbath suhu $65^{\circ} \mathrm{C}$ selama 30 menit, kemudian inokulasi kultur tunggal L. Casei sebanyak $5 \%$, pengemasan dalam wadah kecil (cup), setelah itu yoghurt sinbiotik yang sudah dikemas di inkubasi pada suhu $37^{\circ} \mathrm{C}$ selama 24 jam, penyimpanan yoghurt sinbiotik dilakukan pada suhu dingin lalu diuji organoleptik.

\section{Analisis Mutu Yoghurt Sinbiotik}

Analisis organoleptik, pengujian terhadap tingkat kesukaan (Susiwi, 2009). Evaluasi mutu yoghurt sinbiotik formulasi terbaik pada tahap I dianalisis pada tahapan ke 2, meliputi kimia $\mathrm{pH}$ (AOAC, 2005), total asam tertitrasi (TAT) (AOAC, 2005), analisis proksimat kadar abu (AOAC, 2005), kadar lemak metode hidrolisis asam (AOAC, 2005), kadar protein metode kjeldhal (AOAC, 2005), dan kadar inulin (AOAC, 2005). Analisis fisik viskositas (AOAC, 2005). Analisis mikrobiologi meliputi perhitungan jumlah total bakteri asam laktat (BAL) dengan pengamatan pada hari ke 7 dan 14 (BSN, 2009).

\section{HASIL DAN PEMBAHASAN \\ Organoleptik Yoghurt Sinbiotik Optimasi Pure Pisang Barangan Aroma}

Aroma merupakan salah satu parameter mutu yang penting pada yoghurt. Pada penelitian pembuatan minuman sinbiotik, dengan penambahan bahan baku pure pisang barangan. Aroma yang terbentuk pada minuman sinbiotik selain merupakan kontribusi dari senyawa volatil oleh bakteri asam laktat, juga merupakan kontribusi dari senyawa volatil yang terdapat pada puree pisang. Uji rating hedonik atribut aroma minuman sinbiotik dapat dilihat pada Tabel 1. 
Tabel 1. Uji rating hedonik atribut aroma minuman sinbiotik

\begin{tabular}{ll}
\hline Perlakuan & Nilai \\
\hline P0 (Susu skim 276m L+ Pure pisang barangan 0) & $5,6^{\mathrm{b}}$ \\
P1 (Susu skim 184 mL+ Pure pisang barangan 92 mL) & $2,8^{\mathrm{a}}$ \\
P2 (Susu skim 138 mL+ Pure pisang barangan 138 mL) & $6,1^{\mathrm{c}}$ \\
P3 (Susu skim 92 mL+ Pure pisang barangan 184 mL) & $2,6^{\mathrm{a}}$ \\
\hline
\end{tabular}

Keterangan : Angka- angka yang diikuti oleh huruf yang berbeda menunjukkan perbedaan yang sangat nyata menurut uji DMRT $a=5 \%$

1.Sangat tidak suka 2.Tidak suka 3.Agak tidak suka 4.Netral 5.Agak suka 6.Suka 7.Sangat suka

Hal ini bisa dilihat dari Tabel 1 yang menunjukkan penilaian panelis terhadap yoghurt sinbiotik dengan penambahan pure pisang barangan, penilaian tingkat kesukaan tertinggi yaitu pada sampel P2. Penambahan pure pisang semakin banyak maka akan menambah aroma asam yoghurt semakin lebih kuat, karena terbentuknya proses fermentasi antara susu dan pure pisang (Hariono dkk, 2011). Sesuai dengan penelitian (Wibawanti \& Rinawidiastuti, 2018), yoghurt dengan penambahan buah-buahan akan menghasilkan aroma lebih asam dibandingkan dengan yoghurt biasa tanpa penambahan (Yoghurt plain). Formulasi susu skim lebih banyak dibandingkan pure pisang tidak disukai oleh panelis, namun hal ini berbanding terbalik karena jika penambahan pure yang semakin sedikit akan menghasilkan aroma yang tidak terlalu asam, bisa jadi karena faktor dari panelis yang memiliki tingkat kesukaan yang berbeda dan indra penciuman yang berbeda.

\section{Tekstur}

Tekstur yang dihasilkan pada semua formulasi yoghurt sinbiotik berada pada kisaran kental semi padat. Tekstur tersebut sudah memenuhi persyaratan SNI 01.2981-2009 yaitu cairan kental semi padat. Hasil uji rating hedonik atribut tekstur dengan penilaian panelis pada formulasi minuman sinbiotik dapat dilihat pada Tabel 2.

Tabel 2. Uji Rating Hedonik Atribut Tekstur Yoghurt Sinbiotik

\begin{tabular}{lc} 
Perlakuan & Nilai \\
\hline P0 (Susu skim 276 mL+ Pure pisang barangan 0) & $5,6^{\mathrm{b}}$ \\
P1 (Susu skim 184 mL+ Pure pisang barangan 92 mL) & $2,6^{\mathrm{a}}$ \\
P2 (Susu skim 138 mL+ Pure pisang barangan 138 mL) & $6,2^{\mathrm{c}}$ \\
P3 (Susu skim 92 mL+ Pure pisang barangan 184 mL) & $2,3^{\mathrm{a}}$ \\
\hline
\end{tabular}

Keterangan : Angka- angka yang diikuti oleh huruf yang berbeda menunjukkan perbedaan yang sangat nyata menurut uji DMRT a $=5 \%$

Keterangan: 1.Sangat tidak suka 3. Agak tidak suka 5. Agak suka 7. Sangat suka
2.Tidak suka
4. Netral
6. Suka

Hasil uji rating hedonik pada Tabel 2 tingkat kesukaan panelis terhadap tekstur yoghurt sinbiotik bisa diterima oleh panelis, dapat dilihat penilaian panelis dengan tingkat kesukaan tertinggi yaitu pada formulasi sampel P2. 
Hampir sama dengan alasan penilaian aroma, menurut panelis rata-rata untuk tekstur lebih suka dengan formulasi penambahan pisang yang sedikit, karena jika terlalu banyak pisang yang ditambahkan akan membuat tekstur yang agak sedikit kasar saat dicicipi. Hal ini sesuai dengan penelitian (Desnilasari \& Lestari, 2014). Pure pisang yang ditambahkan memiliki granula yang lebih besar dibandingkan dengan susu skim sehingga menimbulkan kesan kasar saat saat dicicipi, selain itu komponen protein yang terdapat pada susu skim mengalami penggumpalan curd yang teksturnya padat dan lembut, sedangkan pure pisang tidak mengalami penggumpalan. Menurut (Eke dkk, 2014) yoghurt dengan penambahan pisang terlalu banyak, maka semakin banyak pula kandungan serat nya dan akan berpengaruh pada tekstur yoghurt semakin kasar, dan semakin sedikit serat pisang tekstur yoghurt semakin lembut. Serat pangan adalah bagian makanan yang tidak dapat terhidrolisis karena, serat pangan merupakan bagian dari tumbuhan yang dapat di konsumsi dan tersusun dari karbohidrat yang memiliki sifat resisten atau tidak bisa terglatinasi (Damayanti, 2020).

Formulasi sampel yoghurt sinbiotik P1, dengan susu skim lebih banyak dibandingkan dengan pure pisang tekstur yoghurt sinbiotik kurang disukai oleh panelis, karena formulasi yang tidak seimbang antara susu skim dan pure pisang kurang menyatu atau tercampur sehingga menghasilkan formulasi yang kurang tepat, tekstur yang dihasilkan lembut kental namun pure pisang yang ditambahkan kurang merata sehingga terpisah-pisah dan tidak bisa saling berikatan dengan susu skim selain itu tidak bisa terjadi penggumpalan pada pure pisang.

\section{Rasa}

Rasa yang terbentuk pada yoghurt sinbiotik dipengaruhi oleh beberapa faktor, diantaranya kemampuan bakteri yang digunakan sebagai kultur untuk melakukan pemecahan laktosa. Selain itu rasa juga dipengaruhi oleh bahan baku yang digunakan dalam pembuatan yoghurt (Analianasari, 2019). Hasil uji organoleptik rating hedonik pada Tabel 3 menunjukkan bahwa penilaian panelis terhadap atribut rasa yang paling disukai yaitu sampel P2, dan sampel dengan tingkat kesukaan panelis terendah yaitiu pada sampel P3.. Menurut panelis jika ditambahkan dengan puree pisang yang semakin banyak maka rasa dari yoghurt akan menjadi lebih asam dan diakhir meninggalkan rasa puree pisang agak sedikit kasar dilidah. Menurut penelitian dari (Purbasari dkk., 2014) penambahan formulasi pure pisang semakin banyak juga akan menimbulkan rasa agak sepat dan terasa kasar dilidah, karena rasa sepat pada pisang 
disebabkan adanya kandungan tanin yang dapat menggumpalkan protein sehingga terjadi penyamakan pada bagian mukosa rongga mulut. Hasil formulasi minuman sinbiotik dengan perbandingan susu skim lebih banyak dibandingkan dengan puree pisang yaitu pada formulasi sampel P1 panelis kurang menyukai formulasi tersebut namun dilihat dari penelitian sebelum nya hasil tersebut berbanding terbalik. Menurut (Azni, 2019) faktor yang mempengaruhi yaitu tingkat kesukaan panelis dan saat proses pengadukan sampel mungkin kurang merata sehingga mempengaruhi rasa yang dihasilkan.

Tabel 3. Uji Rating Hedonik Atribut Rasa Yoghurt Sinbiotik

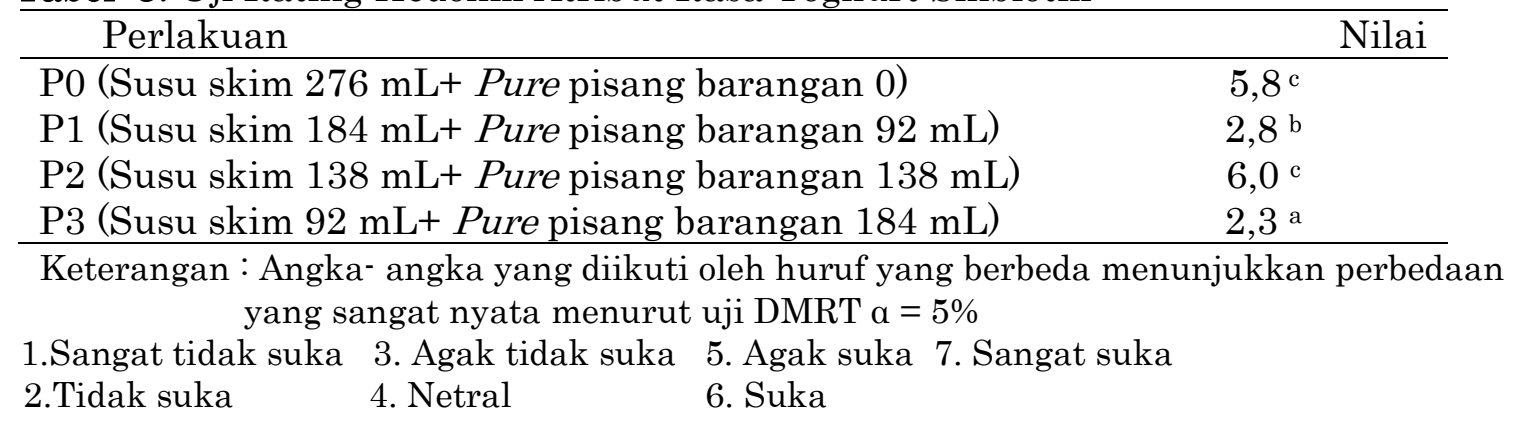

\section{Kenampakan}

Kriteria kenampakan merupakan parameter organoleptik yang cukup penting dinilai oleh panelis, karena jika kesan kenampakan baik dan disukai, maka panelis akan lebih tertarik melihat parameter organoleptik aroma, tekstur dan rasa. Kenampakan merupakan faktor penting untuk menentukan mutu suatu produk. Kenampakan penilaian produk yoghurt sinbiotik dilihat dari segi warna, penilaian warna mempengaruhi kualitas dan daya tarik produk. Dapat dilihat pada Tabel 4 Uji rating hedonik atribut kenampakan pada minuman sinbiotik.

Tabel 4. Uji Rating Hedonik Atribut Kenampakan Yoghurt Sinbiotik

$$
\text { Perlakuan }
$$

Nilai

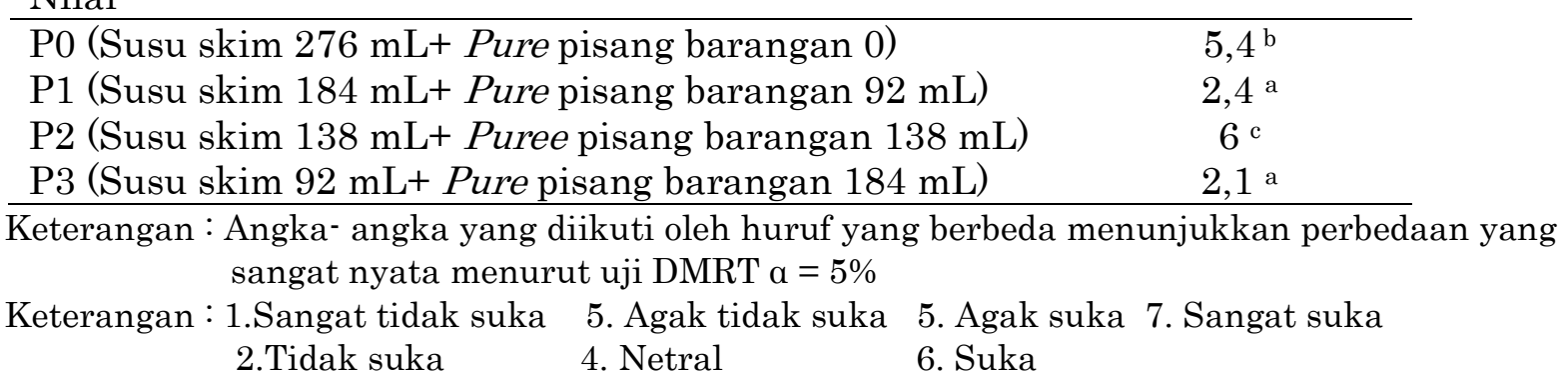

Formulasi yang memiliki tingkat kesukaan paling tinggi menurut panelis pada Tabel 4 adalah formulasi sampel P2, dan sampel dengan tingkat kesukaan panelis terendah yaitu sampel P3. Menurut panelis rata-rata lebih suka dengan penambahan pure pisang yang lebih sedikit, karena selain dilihat dari tekstur, aroma, dan rasa, kenampakan warna produk yoghurt sinbiotik dengan sedikit 
penambahan pure pisang lebih menarik dibandingkan dengan penambahan pure pisang yang lebih banyak banyak. Kenampakan warna pada produk yoghurt sinbiotik dengan penambahan pure pisang yang lebih banyak tampak warnanya lebih pekat. Dapat dilihat pada Gambar 1 formulasi yoghurt sinbiotik. Formulasi terbaik pada sampel yoghurt sinbiotik pada tahap satu, kemudian dilakukan tahapan selanjutnya yaitu analisis mutu yoghurt sinbiotik meliputi analisis mutu kimia, analisis mutu fisik, dan analisis mutu mikrobiologi.

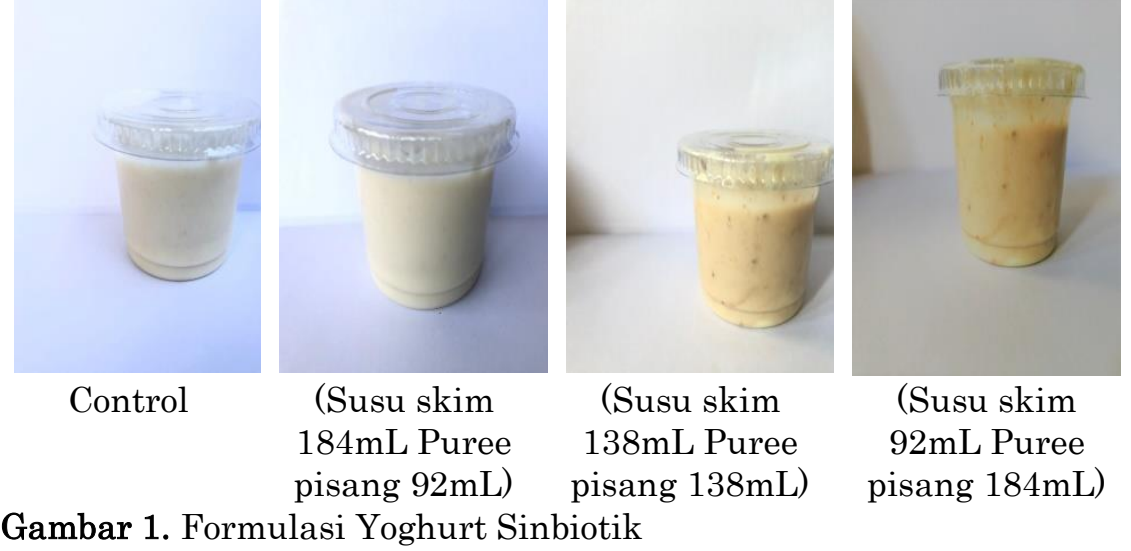

\section{Analisis Mutu Kimia Yoghurt Sinbiotik}

Mutu kimia merupakan salah satu hal yang perlu diketahui dalam pembuatan suatu produk. Analisis mutu kimia sangat penting untuk dilakukan analisis karena sangat mempengaruhi kualitas dari produk minuman sinbiotik. Menurut (Yulianti dkk, 2017) analisis kimia pada produk untuk mengetahui kandungan atau nilai gizi yang ada di dalam produk minuman sinbiotik. Pengukuran mutu kimia minuman sinbiotik meliputi $\mathrm{pH}$, total asam tertitrasi (TAT), dan kadar inulin produk minuman sinbiotuk. Hasil analisis mutu kimia produk minuman sinbiotik dapat dilihat pada Tabel 5.

Tabel 5. Hasil Analisis Mutu Kimia Yoghurt Sinbiotik

\begin{tabular}{ccc}
\hline Kriteria Uji & Analisa & SNI 01.2981:2009 \\
\hline pH (Derajat Keasaman) & 4,02 & $3,8-4,4$ \\
TAT (\% Asam Laktat) & 1,05 & $0,5-2,0$ \\
\hline
\end{tabular}

\section{pH (Derajat Keasaman)}

Produk minuman sinbiotik yang dihasilkan memiliki $\mathrm{pH} 4,02$. Nilai ini sudah memenuhi $\mathrm{pH}$ yoghurt yang baik. Menurut SNI 2981:2009 nilai $\mathrm{pH}$ yoghurt berkisar antara 3,8-4,4. Hasil penelitian membuktikan bahwa yoghurt yang dihasilkan dengan nilai $\mathrm{pH}$ 4,02 sudah mampu menggumpalkan kasein dan membentuk tekstur yang baik, selain itu dengan tingkat keasaman tersebut sudah menghasilkan flavour yoghurt yang khas yaitu aroma asam susu fermentasi. 


\section{Total Asam Tertitrasi (TAT)}

Hasil nilai total asam tertitrasi (TAT) produk yoghurt sinbiotik pada Tabel 5 menunjukkan sampel terpilih minuman sinbiotik sebesar $1,05 \%$. Nilai total asam tertitrasi (TAT) tersebut sudah cukup dalam mengasilkan tekstur yang lembut serta flavor asam yang cukup kuat. Selain itu hasil tersebut menurut SNI 01.2981-2009 tentang standart mutu yoghurt masih mempunyai nilai yang baik yaitu termasuk dalam kisaran 0,5-2,0\%.

\section{Kadar Inulin}

Penentuan kadar inulin pada produk yoghurt sinbiotik penting dilakukan untuk, mengetahui jumlah prebiotik yang terkandung dalam produk agar memenuhi persyaratan suatu produk yang dikatakan berprebiotik. Penentuan kadar inulin ini sangat mempengaruhi kualitas yoghurt sinbiotik, salah satu faktor utama yang menentukan kadar prebiotik agar memenuhi persyaratan atau sesuai dengan standart yaitu, bahan baku yang digunakan atau penambahan bahan yang memiliki kadar inulin yang tinggi. Hasil kandugan kadar inulin dapat dilihat pada Tabel 6.

Tabel 6. Hasil Analisis Mutu Kimia Formulasi terbaik Yoghurt Sinbiotik.

\begin{tabular}{ccc}
\hline Kriteria Uji & Analisa & (Frank, 2005) \\
\hline Kadar Inulin g/100g & 2,88 & $1-3 \%$ \\
\hline
\end{tabular}

Hasil penelitian minuman sinbiotik menunjukkan pada Tabel 10 bahwa kadar inulin pada akhir produk minuman sinbiotik sebesar 2,88 g/100g. Jumlah ini sudah memenuhi persyaratan produk berprebiotik, karena menurut (Boeni dkk., 2012) produk dikatakan berprebiotik yaitu sebesar 1-3\% per kemasannya. Penelitian yang sama tentang minuman simbiotik yaitu menggunakan inulin pisang dan penambahan inulin komersil hasil produk akhir sebesar 3,88 g/100g (Desnilnasari, 2014).

\section{Analisis Proksimat}

Hasil analisis proksimat memberikan gambaran secara umum nilai gizi dari produk yoghurt sinbiotik. Hasil uji proksimat yoghurt sinbiotik dapat dilihat pada Tabel 7.

Tabel 7. Hasil Analisis Proksimat Formulasi Terpilih Yoghurt Sinbiotik

\begin{tabular}{ccc}
\hline Kriteria Uji & Kandungan (\%) & SNI 01.2981:2009 \\
\hline Kadar Abu & 0,87 & Maks. 1,0 \\
Kadar Lemak & 4,10 & Min. 3,0 \\
Kadar Protein & 4,58 & Min. 2,7 \\
\hline
\end{tabular}

\section{Kadar Abu}


Hasil analisis kadar abu minuman sinbiotik sebesar 0,87\% hasil tersebut sudah sesuai dengan SNI Yoghurt 01.2981-2009 sebesar maksimal 1,0\%. Hasil kandungan mineral yang terdapat pada produk yoghurt sinbiotik dipengaruhi oleh bahan baku yang digunakan yaitu pisang barangan dan susu skim. Menurut (Buckle et al. 2012) menyatakan bahwa kandungan mineral pada susu skim adalah sekitar 8\%. Artinya bahan baku yang digunakan yaitu susu skim dapat menyumbang atau menambah kandungan mineral pada produk yoghurt sinbiotik.

\section{Kadar Lemak}

Hasil uji proksimat kadar lemak pada yoghurt sinbiotik yaitu sebesar 4,10\% . Hasil kadar lemak tersebut sudah sesuai dengan SNI Yoghurt 01.29812009 yaitu manimal 3,0\%. Namun hasil penelitian yoghurt sinbiotik ini kadar lemak nya lebih tinggi dibandingkan dengan penelitian sebelumnya yaitu sebesar 0,20\% yang dilakukan oleh (Desnilnasari \& Lestari, 2014). Kadar lemak yang terkandung pada produk tergantung pada bahan baku yang digunakan dalam pembuatan yoghurt. Kandungan lemak pada susu skim sebesar maksimal 1\% menurut (Anon dkk., 2012). Kandungan lemak pisang barangan sebesar 0,10 (g) menurut penelitian (Auroeret et al., 2912). Dibandingkan dengan penelitian sebelumnya bahan baku jenis pisang yang digunakan berbeda. Selain itu untuk susu skim yang digunakan bisa jadi menggunakan merk yang berbeda atau proporsi susu skim yang berbeda sehingga mempengaruhi hasil kandungan kadar lemak yang ada di produk yoghurt.

\section{Kadar Protein}

Hasil kadar protein pada produk sebesar 4,58\%. Hasil kadar protein ini sudah sesuai dengan SNI Yoghurt 01.2981-2009 yaitu minimal 2,7\%, bahkan lebih besar dibandingkan penelitian sebelumnya yang dilakukan oleh (Desnilasari, 2014) kadar protein yoghurt sebesar 2,79\%. Hal ini dipengaruhi karena adanya penyumbangan kandungan protein yang ada didalam bahan baku yang digunakan yaitu susu skim. Selain itu menurut, (Santoso dkk, 2015) kandungan protein yang tinggi dipengaruhi karena adanya penambahan pisang pada produk yoghurt, semakin banyak protein yang terlarut dalam bahan pangan makin tinggi nilai kadar protein produk akhir. Penelitian tentang yoghurt telah dilakukan oleh (Restuti \& Rahmawati, 2020) hasil kadar protein sebesar 4,37\%, kandungan kadar protein pada produk yoghurt dipengaruhi oleh kadar protein yang terkandung dalam bahan baku pisang yang memiliki kadar protein sebesar $1,1 \mathrm{~g}$ per $100 \mathrm{~g}$ buah pisang.

\section{Analisis Mutu Fisik}




\section{Viskositas}

Analisis mutu fisik pada yoghurt sinbiotik merupakan indikator yang sangat penting, karena untuk mengetahui karakteristik dari yoghurt. Analisis mutu fisik meliputi viskositas. Pengukuran viskositas merupakan pengukuran kekentalan untuk mengetahui tekstur dari produk yoghurt sinbiotik. Hasil analisis mutu fisik produk yoghurt sinbiotik dapat dilihat pada Tabel 8.

Tabel 8. Hasil Analisis Mutu Fisik Formulasi Terpilih Yoghurt Sinbiotik

\begin{tabular}{ccc}
\hline Kriteria Uji & Analisa & Literatur \\
\hline Viskositas (cP) & 11,05 & $8,28-13,00$ \\
\hline Sumber : *(Pangastuti dkk., 2018) &
\end{tabular}

Hasil penelitian yoghurt sinbiotik pada Tabel 8 menunjukkan bahwa nilai viskositas sebesar 11,05 cP, hasil tersebut sudah sesuai dengan penelitian yang dilakukan oleh (Setianto dkk, 2014). Penelitian yang sama tentang yoghurt dengan penambahan pisang telah dilakukan oleh (Krisnaningsih dkk., 2020) nilai viskositas sebesar 8,95 cP, nilai viskositas dipengaruhi oleh lama proses fermentasi. Semakin lama waktu fermentasi akan meningkatkan viskositas, bahwa peningkatan terjadi karena denaturasi protein pada yoghurt yang akhirnya terkoagulasi dan meningkatkan viskositas.

\section{Analisis Mutu Mikrobiologi}

\section{Jumlah Total Bakteri Asam Laktat (BAL)}

Pentingnya uji mikrobiologi pada sampel terpilih yoghurt sinbiotik, untuk mengetahui mutu produk secara mikrobiologi serta pengamatan terhadap jumlah total bakteri asam laktat (BAL) dari segi kualitas dan vabilitasnya selama penyimpanan dilakukan selama 14 hari, dan dilakukan pengamatan di hari ke 7 dan ke 14. Berikut data hasil jumlah total bakteri asam laktat (BAL) dapat dilihat pada Tabel 9.

Tabel 9. Total Bakteri Asam Laktat (BAL) Yoghurt Sinbiotik

\begin{tabular}{c|c|c}
\hline Hari ke- & $\begin{array}{c}\text { Jumlah Total Bakteri } \\
\text { Asam Laktat (BAL) }\end{array}$ & SNI 01.2981:2009 \\
\hline 7 & $1,29 \times 10^{9} \mathrm{cfu} / \mathrm{mL}$ & Min. $10^{7} \mathrm{cfu} / \mathrm{mL}$ \\
14 & $2,42 \times 10^{9} \mathrm{cfu} / \mathrm{mL}$ & \\
\hline
\end{tabular}

Hasil perhitungan total bakteri asam laktat yang terdapat dalam produk minuman sinbiotik formulasi terpilih berdasarkan tabel 9 pada hari ke- 7 sebanyak $1,29 \times 10^{9} \mathrm{cfu} / \mathrm{mL}$, jumlah tersebut sudah memenuhi persyaratan suatu produk dapat dikatakan probiotik. Menurut SNI Yoghurt 01.2981-2009 sebesar minimal $10^{7} \mathrm{cfu} / \mathrm{ml}$, pada umumnya untuk penyimpanan yoghurt sinbiotik 
dengan penyimpanan hari ke 7 sudah dapat menghasilkan jumlah bakteri asam laktat yang dapat memenuhi standart probiotik yoghurt sinbiotik. Jumlah total

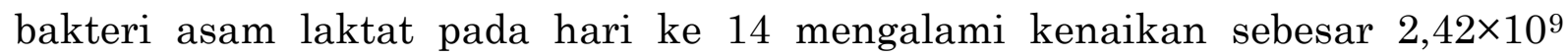
$\mathrm{cfu} / \mathrm{mL}$.

Hasil total bakteri asam laktat mengalami peningkatan dari pengamatan hari ke 7 hingga hari ke 14. Salah satu faktor yag mempengaruhi peningkatan total bakteri asam laktat adalah bahan yang digunakan untuk pembuatan yoghurt sinbiotik yaitu susu skim dan penambahan pisang barangan. Hal ini sesuai dengan penelitian (Andarwulan, 2015) semakin meningkat jumlah total bakteri asam laktat, karena bakteri yang tumbuh dalam pangan bersifat hetrotropik, memerlukan zat organik berupa karbohidrat, protein, lemak, sumber karbon, dan energi sebagai media tumbuh. Artinya susu skim dan penambahan pisang dapat meningkatkan nilai total bakteri asam laktat.

\section{KESIMPULAN}

Rasio pure pisang barangan sampel terbaik karakteristik organoleptik yaitu P2 (Susu skim $138 \mathrm{~mL}+$ Puree pisang barangan $138 \mathrm{~mL}$ ). Yoghurt sinbiotik telah diuji mutunya secara kimia, fisik, dan mikrobiologi. Hasil menunjukkan nilai mutu kimia pH 4,02, Total Asam Tertitrasi (TAT) 1,05 \%, Kadar Inulin 2,88\%. Hasil kadar abu sebesar 0,87\%, kadar lemak 4,10\%, dan kadar protein 4,58\%. Hasil jumlah total bakteri asam laktat (BAL) hari ke- 7 sebesar $1,29 \times 10^{9}$ $\mathrm{cfu} / \mathrm{mL}$ dan hari ke- $142,42 \times 10^{9} \mathrm{cfu} / \mathrm{mL}$.

\section{DAFTAR PUSTAKA}

Azni, I. N. 2019. Formulasi Bahan Makanan Campuran Berbahan Dasar Kedelai, Beras Merah, Dan Pisang Kepok Untuk Makanan PendampingAsi. Jurnal Teknologi Pangan dan Kesahatan Journal of Food Technology and Health, 1(1), pp. 1-7. doi: 10.36441/jtepakes.v1i1.164.

Andarwulan,N.,F. Andriani. 2015. Quality attributes of yogurt with Lactobacillus casei and various prebiotics. Journal Agrotechnology 40,1808-1814.

Boeni, S. dan Pourahmad, R. (2012). Use of inulin and probiotic lactobacilli in synbiotic yogurt production. Annals of Biological Research 3(7): 3486-3491.

Desnilnasari, D., \& Lestari, N. P. A. 2014. Formulasi Yoghurt sinbiotik Dengan Penambahan Inulin Pisang Sebagai Prebiotik. Journal Agritech, 34(3). https://doi.org/10.22146/agritech.9453.

Damayanti, S., Bintoro, V. P., \& Setiani, B. E. 2020. Pengaruh Penambahan Tepung Pisang terhadap Sifat Fisik Minuman Sinbiotik. Journal of Nutrition College, 9(3), pp. 180-186.

Eke, Ejiofor J., Beleya, E., \& Onyenorah, N. 2014. The Effect of Processing Methods on The Functional and Compositional Properties of Jackfruit 
Seed Flour. International Journal of Nutrition and Food Sciences, 3(3), pp. 166-173. https://doi.org/10.11648/j.ijnfs.20140303.15.

Gourbyre., Gorbach, SL. 2012. The effect of milk and Lactobacillus feeding in human intestinal bacterial enzyme activity. American Journal of Clinical Nutrition, 39, pp.756-761.

Hariono Kunsman, Jr., \& Deane, DD. 2011. Acetheladehdye Production by Combined Yoghurt Cultures. Journal Dairy Sci, 54 (7), pp.1080-2.

Krisnaningsih,A. T. J., T. I.W. Kustyorini, M. Meo, 2020. Pengaruh Penambahan Pati Talas (Colocasia esculenta) Sebagai Stabilizer Terhadap Viskositas dan Uji Organoleptik Yogurt. Jurnal Sains Peternakan, 8(1), pp:66-76.

Latimer, H,. Gregor JV., \& White CH. 2017. Effect of Sweeteners on Major Volatile Compounds and Flavour of Yoghurt. Journal Dairy sciences, pp.21-22.

Nurbaya, S. R., \& Estiasih, T. 2013. Variasi Penambahan Tepung Pisang dalam Minuman Sinbiotik. Jurnal Pangan dan Agroindustri, 1(1), pp.46-55.

Purbasari, A., Y. B. Pramono \& S. B. M. Abduh. 2014. Nilai pH, Kekentalan, Cita Rasa dan Kesukaan pada Susu Fermentasi dengan Perisa Alami Jambu Air (Syzygium sp). Jurnal Aplikasi Teknologi Pangan. 3 (4), pp. $174-177$.

Sarifudin, A., Ekafitri, R., Surahman, D. N., \& Putri, S. K. D. F. A. 2015. Pengaruh Penambahan Telur pada Kandungan Proksimat, Karakteristik Aktivitas Air Bebas (aw) dan Tekstural Snack Bar Berbasis Pisang (Musa paradisiaca). Agritech, 35(1), pp.1-8. https://doi.org/10.22146/agritech.9413

Santoso, M. T., Hidayati, L., \& Sudjarwati, R. 2015. Pembuatan Soyghurt Sinbiotik dengan Menggunakan Kultur Campuran Bifidobacterium bifidum, Streptococcus thermophilus dan Lactobacillus casei galur Shirota. Teknologi dan Kejuruan: Jurnal teknologi, Kejuruan dan Pengajarannya, $37(2)$.

Setianto, Y.C., Pramono, Y.K., Mulyani, S. 2014. Nilai pH, Viskositas, dan Tekstur Yoghurt Drink dengan Penambahan Ekstrak Salak Pondoh (Salacca zalacca). Jurnal. Aplikasi Teknologi Pangan 3 (3), pp.110-113.

Voidarou, C., Antoniadou, M., Rozos, G., Tzora, A., Skoufos, I., Varzakas, T., Lagiou, A. \& Bezirtzoglou, E. 2021. Fermentative Foods: Microbiology, Biochemistry, Potential Human Health Benefits and Public Health Issues. Foods, 10 (1), pp. 6-9. doi: 10.3390/foods10010069.

Yulianti, S., Ratman, R., \& Solfarina, S. 2017. Sifat kimia, mikrobiologi, dan organoleptik yogurt yang menggunakan persentase Lactobacillus casei dan kadar gula yang berbeda. Jurnal Peternakan 1(8), pp. 21-24.

Wibawanti, J.M.W., \& Rinawidiastuti. 2018. Sifat Fisik dan Organoleptik Yogurt Drink Susu Kambing Dengan Penambahan Ekstrak Kulit Manggis (Garcinia mangostana L.). Jurnal Ilmu dan Teknologi Hasil Ternak, April 2018, pp 27-37. DOI: 10.21776/ub.jitek.2018.013.01.3. 